\title{
Cannibalism, refugia and the molting blue crab
}

\author{
Clifford H. Ryer ${ }^{1, *}$, Jacques van Montfrans ${ }^{2}$, Kurt E. Moody ${ }^{2}$ \\ ${ }^{1}$ Fisheries Behavioral Ecology Group, Alaska Fisheries Science Center, National Marine Fisheries Service, NOAA, and \\ Department of Fisheries \& Wildlife, Oregon State University, Hatfield Marine Science Center, Newport, Oregon 97365, USA \\ ${ }^{2}$ College of William and Mary, School of Marine Science, Virginia Institute of Marine Science, Gloucester Point, \\ Virginia 23062, USA
}

\begin{abstract}
In this study, we examined how habitat and tidal stage influence predation upon molting blue crabs Callinectes sapidus. On 3 separate occasions we monitored the survival of tethered soft crabs in each of 2 different-sized marsh creeks and 2 seagrass sites, during both low and high tides. On one of these occasions, we also tethered hard crabs. Survival was much lower for soft crabs than for hard crabs, indicating that crabs may be particularly vulnerable when they molt. In both seagrass and marsh creeks. there was a tidal influence upon soft crab survival, with greater survival during low tides. There was no generalized difference in survival of soft crabs between habitats, i.e. marsh creek versus grassbed. Survival was high in the small marsh creek, but lower in the large marsh creek. In both creeks survival remained relatively constant throughout the summer. In contrast, survival did not differ between the 2 seagrass sites and was comparable to that in the small marsh creek early in the summer, but decreased to levels comparable to the large marsh creek by summers end. In the marsh creek, micro-habitat also influenced survival, with greater survival along the creek edge micro-habitats than in the creek centers Cannibalism was the only identifiable source of mortality among tethered crabs. These results demonstrate that where and when a crab molts may greatly influence its chances for survival.
\end{abstract}

KEY WORDS: Eelgrass $\cdot$ Marsh creeks $\cdot$ Predation $\cdot$ Selfish herd $\cdot$ Tidal

\section{INTRODUCTION}

Crustaceans undergo ecdysis (molting) numerous times throughout their lives. In many species, ecdysis may render individuals vulnerable to an enlarged suite of predators. Not surprisingly, some crustaceans seek shelter as ecdysis approaches (Reaka 1976, Tamm \& Cobb 1978), whereas others segregate themselves from non-molting conspecifics, thereby reducing risk of injury or mortality (Lipcius \& Hernkind 1982). Thus, behavioral responses to predation risk during ecdysis may lead to changes in the spatial and temporal distribution of individuals within and between habitats (Hines et al. 1987, Ryer et al. 1990).

The blue crab Callinectes sapidus is an ideal species for examining habitat-related mortality during molt and the selective advantage of shelter-seeking behav-

•E-mail: ryerc@ccmail.orst.edu ior. Blue crabs possess a heavily armored exoskeleton during intermolt, but are soft, defenseless and unable to flee predators during their molt and for several minutes immediately afterwards. Thus, they may be extremely vulnerable to predation during ecdysis. In addition, blue crabs occupy a wide variety of estuarine habitats and are highly mobile, making it feasible for them to move between and to select habitats on the basis of their value as a molting refuge.

Our most complete understanding of molt-related habitat partitioning in blue crabs comes from the Rhode River, a subestuary of the central Chesapeake Bay (USA). Males approaching ecdysis migrate from the river basin to tidal marsh creeks where molting occurs (Hines et al. 1987). These movements are thought to be associated with reduced predation pressures in creeks (Shirley et al. 1990). In contrast, for pubertal females the availability of mates is thought to be more important than molting refugia, and pubertal females are most abundant in the deeper subtidal 
habitats of the river basin where mature inter-molt males are abundant (Shirley et al. 1990). Indeed, mating may actually alleviate the pubertal female's need to seek out molting refugia, because for several days before, and several hours after ecdysis, the female is cradled and aggressively defended by the inter-molt male, presumably reducing her vulnerability to predators. Pre-pubertal females occur in such low numbers in the Rhode River that it is unclear where they molt.

In the lower Chesapeake Bay, unlike the Rhode River, seagrass meadows are a common feature of shallow nearshore areas. The structural complexity of this habitat provides juvenile blue crabs with a refuge from predation (Orth \& van Montfrans 1987, Wilson et al. 1987). In an earlier study, we documented greater molting activity in a grassbed than in a nearby tidal marsh creek (Ryer et al. 1990). We hypothesized that blue crabs may utilize seagrass beds as a molting refuge because of reduced predation pressure relative to other shallow water habitats, e.g. tidal marsh creeks.

In this paper, we present results from tethering experiments utilizing recently molted (soft) crabs designed to test hypotheses regarding where and when blue crabs molt. First, we compared the survival of tethered hard and soft crabs to test the hypothesis that soft crabs are indeed more vulnerable to predation. Next, we tested the hypothesis that predation pressure is lower in grassbeds than in marsh creeks. In making this comparison between habitats, we also examined the role of tidal stage, because our observations, as well as anecdotal information from local crab shedding operations, suggested that molting activity in grassbeds is greatest during low tides. If this observed pattern has evolved in response to predation pressure, we would expect survival of soft crabs tethered in grassbeds to be greater during low tides than during high tides. For the marsh creeks we predicted the opposite effect, greater survival during high tides. During low tides predators that do not leave marsh creeks, particularly intermolt blue crabs, are concentrated in the remaining sub-tidal areas (van Montfrans et al. 1991), potentially increasing aggressive interactions and cannibalism. Lastly, we examined the influence of marsh creek micro-habitat upon predation pressure. We predicted greater survival along the more structurally complex creek edges than in the creek centers.

Our goal in tethering crabs was not to estimate actual rates of predation upon soft crabs in the field, but to examine relative rates of predation between various treatments. As such, we explicitly assumed that our experimental intervention modified ecological interactions to an equal extent across treatments. The validity of this assumption has recently been questioned with regard to tethering techniques (Peterson \& Black
1994) However, a recent laboratory study demonstrated no biases associated with tethering juvenile intermolt blue crabs on vegetated versus unvegetated substrates (Pile et al. 1996), and, as we shall demonstrate, it is reasonable to assume there was no treatment-specific bias in our experimental system either

\section{MATERIALS AND METHODS}

Experiments. Field tethering experiments were conducted during June, July and August 1990 on full moons, when peak blue crab molting activity occurs (Ryer et al. 1990). Tethered crabs were deployed and retrieved at night; anecdotal information from commercial shedders suggested greater molting at night. Our experimental design entailed tethering soft crabs in 2 neighboring marsh creeks and 2 sites in a seagrass meadow during both high and low tides. Both marsh creeks and seagrass sites are located on the western shore of Browns Bay, lower Chesapeake Bay, Virginia (Fig. 1). The larger of the 2 marsh creeks is $12 \mathrm{~m}$ wide at its mouth, several hundred meters long and drains an extensive Spartina alterniflora marsh. Most of the creek bottom remains submerged at low tide with 3 large pools having depths exceeding $2 \mathrm{~m}$. This creek was part of an earlier study of temporal periodicity of molting by Callinectes sapidus (Ryer et al. 1990). The smaller marsh creek is $5 \mathrm{~m}$ wide at its mouth, drains a similar but smaller marsh area, and most of the creek

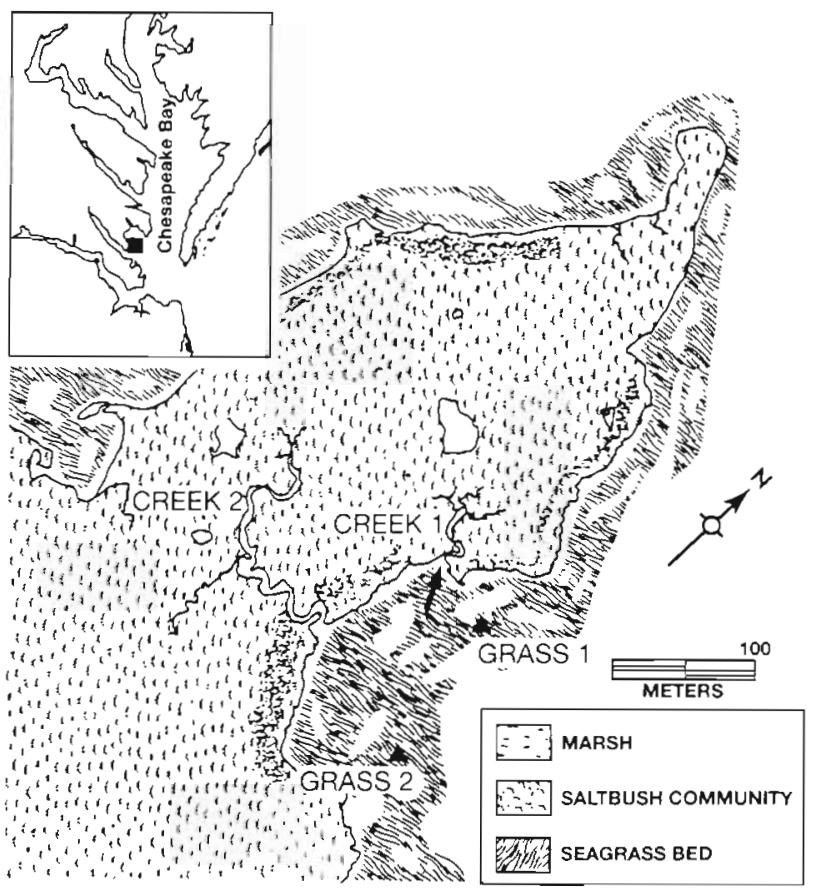

Fig. 1. Study sites in the lower Chesapeake Bay (USA) 
bottom ebbs dry during normal low tides except for narrow riffles and 3 shallow pools ( $<1 \mathrm{~m}$ depth). Observations from a previous study indicated that crabs in the smaller creek typically remain buried in the creek bed or in the tide pools during low tide (van Montfrans et al. 1991). Both seagrass sites (mixed Zostera marina and Ruppia maritima) are located approximately $300 \mathrm{~m}$ offshore from the 2 marsh creeks. Water depths at both grassbed sites were approximately 1.5 and $0.5 \mathrm{~m}$ during high and low tides respectively.

Soft crabs were obtained from a commercial crab shedding facility. At the shedding facility, all crabs were removed from water and refrigerated immediately after their molt. Since hardening of the exoskeleton ceases when the crab is removed from water (Oesterling 1984), this assured a uniform degree of softness in all crabs. Only live juvenile males and females, or mature males ranging from approximately 80 to $130 \mathrm{~mm}$ in carapace width were selected. These crabs had molted during the previous night. No effort was made to record the size or sex distributions of soft crabs, or how these may have changed between successive sample dates. Tethering consisted of placing a crab into a thin, plastic mesh $(1 \mathrm{~cm})$ tube which conformed like a body stocking to the shape of the crab. The mesh tube was then knotted at each end, attached to an oyster shell which served as a weight and then tied to a $30 \mathrm{~cm}$ strand of monofilament. Laboratory tests confirmed that neither soft or hard crabs were capable of escaping during a $1 \mathrm{~h}$ period. Although crabs were completely covered by mesh, their walking legs typically protruded through the mesh, making them vulnerable to being nipped off. The mesh bag prevented crabs from walking or swimming off, but since crabs actually engaged in the act of molting cannot walk or swim, we feel our tethering procedure simulated the vulnerability experienced by molting crabs. The mesh bag also prevented burying, but it has been our experience that molting does not occur under the sediment surface (Ryer \& van Montfrans pers. obs.). Crabs were prepared $2 \mathrm{~h}$ prior to experimentation, covered with wet paper towels to prevent desiccation and transported to field sites in coolers. When handled this way and kept cool, soft crabs will survive several days out of water and the exoskeleton will not begin to harden until the crab is put back into water (Ryer \& van Montfrans pers. obs.).

In June, 60 soft crabs were tethered, with approximately equal numbers ( 7 or 8 ) allocated to each combination of tide (high or low) and site (large creek and small creek; seagrass sites 1 and 2). Crabs were randomly placed on the bottom in the grassbed while snorkeling and retrieved $1 \mathrm{~h}$ later. A $25 \mathrm{~cm}$ wire stake attached to free end of the tether was pushed into the sediment to prevent crabs from drifting away. The locations of tethered crabs were marked with bamboo stakes. Tethered crabs were separated by at least $10 \mathrm{~m}$. Procedures in the marsh creeks were the same, except on high tide, when half the crabs were placed in creek edge micro-habitats (i.e. along the edges of creek, in the marsh grass, or in cavities along the creek bank), while the other half were placed in the center of the creeks. During low tides all crabs were placed in the creek centers. Observations were made on types and numbers of predators at each site when tethered crabs were retrieved.

In July 159 soft crabs were tethered. Protocols were the same as in June except that crabs were to be retrieved after $45 \mathrm{~min}$. This was accomplished for both tidal stages in the marsh creeks, but only for low tide at the seagrass sites. High tide soft crabs in the seagrass were retrieved after $1 \mathrm{~h}$.

Eighty soft crabs were tethered during August and retrieved after $45 \mathrm{~min}$. Sixty soft crabs were tethered in the marsh creek and 20 in the grassbed. Soft crabs were equally divided between sites and tides within habitats. However, in the marsh creek all crabs were placed in the creek center, allowing no comparisons between marsh creek micro-habitats. In addition, mesh bags containing crabs were not staked to the bottom in either habitat; instead, they were anchored using a $8 \mathrm{~cm}$ length of $2.5 \mathrm{~cm}$ diameter steel pipe attached by a $3 \mathrm{~m}$ line to a float marking the location. In the marsh, a tag line attached to the float allowed the crabs to be recovered from shore. This methodology precluded observation of predators, but allowed for more rapid retrieval of tethered crabs.

During August, we also concurrently deployed 40 tethered hard crabs, comparable in size to soft crabs, and recovered them after $45 \mathrm{~min}$ to determine if hard crabs were less vulnerable to predation than soft crabs. These were divided equally between habitats, sites and tides.

Statistical analysis. We faced a potential problem in that soft crabs were not tethered for the same length of time throughout the study. For example, during June soft crabs were tethered for $60 \mathrm{~min}$, compared to $45 \mathrm{~min}$ during the following months. We corrected June data by calculating the survival that would have occurred for a $45 \mathrm{~min}$ tether duration, assuming a constant rate of predation over time, and utilized these corrected data in our analysis. We similarly corrected data for grassbed sites during the July high tide.

Hypotheses were tested by multidimensional contingency table analysis using Log-Linear Models (Fienberg 1980). Analysis was limited to 3-way and 2-way tests of independence because of the difficulty associated with interpretation of 4-way and higher tests of independence. Effects were considered significant at 
$p<0.05$. Statistical power $(1-B)$ for 2 -way tests of independence was calculated using a hypothetical 50\% effect size, i.e. the largest proportional survival differing from the smallest by $50 \%$ (Cohen 1977). Power was not calculated for 3-way tests of independence because we were unable to locate references or authoritative sources describing such tests.

First, we examined the relative survival of soft versus hard crabs, tethered during August. Preliminary data analysis indicated there were no differences between the 2 seagrass sites $(G=1.73, \mathrm{df}=1, \mathrm{p}=0.188)$, or between the 2 marsh creeks $(G=0.00, \mathrm{df}=1, \mathrm{p}=1.00)$, with respect to difference in survival between soft and hard crabs. Therefore, data were pooled across sites within each habitat for subsequent analysis. For soft crabs from June, July and August, we conducted separate analyses for each habitat. In the grassbed, we examined the effect of date (June, July, or August), site (replicate sites within a habitat type) and tide (high or low) in a single analysis. For the marsh creeks, a separate analysis of site and tide was conducted for each month, because our tethering protocol in the marsh changed during August, i.e. soft crabs were no longer tethered along creek edges. For June and July, where we had tethered crabs in both creek centers and along creek edges, we examined the influence of these micro-habitats upon soft crab survival. Lastly, we compared soft crab survival between the 2 marsh creeks and the seagrass sites.

\section{RESULTS}

We observed 47 separate instances of one or more intermolt blue crabs cannibalizing tethered soft crabs at the time of recovery. No other species was observed preying upon tethered soft crabs. Blue crabs were observed tearing holes in the mesh bags through which soft crabs were dismembered and removed. During the initial recoveries of July we captured 9 of these crabs, which were visually estimated to range in size from 75 to $160 \mathrm{~mm}$ carapace width. All had what appeared to be soft crab tissue in their guts. In instances where predation had occurred but no predators were observed, bags were either empty or still had soft crab parts in them. In all of these instances, there were holes in the bags.

During August, when both soft and hard crabs were tethered, $95 \%$ of hard crabs survived, compared to $34 \%$ survival for soft crabs. However, tidal stage differentially influenced survival between hard and soft crabs $(G=16.66, \mathrm{df}=1, \mathrm{p}<0.001)$. Hard crabs experienced high survival, regardless of tide, whereas soft crab survival was greatest during low tide (Fig. 2). Differences in survival between hard and soft crabs were

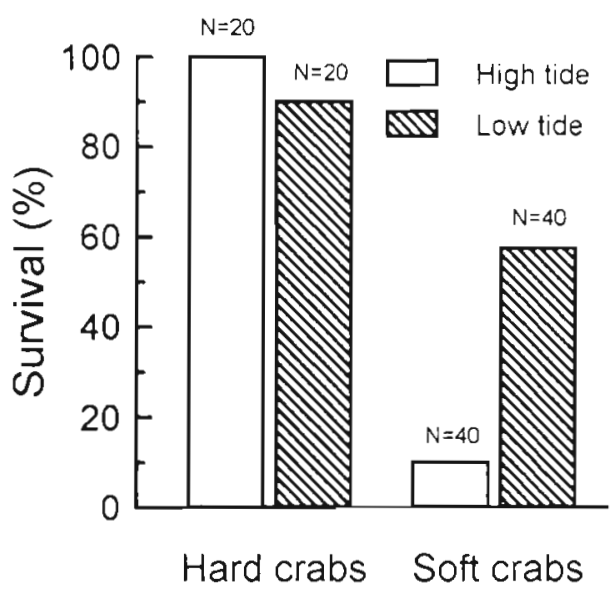

Fig. 2. Callinectes sapidus. Survival (\%) of soft and hard crabs tethered during both high and low tides in August 1990. Data have been pooled across habitats. N: no. of tethered crabs

similar in both seagrass and marsh creek habitats $(G=$ $0.75, \mathrm{df}=1, \mathrm{p}=0.386$ )

In our analysis of tethered soft crabs from June, July and August, survival differed by tidal stage. In the seagrass habitat survival was greatest during low tide (Fig. $3 \mathrm{~A}, G=17.17, \mathrm{df}=1, \mathrm{p}<0.001$ ). This tidal effect was similar at both seagrass sites $(G=0.05, \mathrm{df}=1, \mathrm{p}=$ $0.823)$ and consistent throughout the summer $(G=3.11$. $d f=2, p=0.211$ ). For the marsh creeks, we did not conduct a comprehensive analysis encompassing all 3 months because our tethering methodology in the marsh changed during August. However, separate analyses for each of these months revealed a pattern of greater survival during low tides (Fig. 3B), similar to that observed in the grassbed. This effect was statistically significant for July $(G=8.12, \mathrm{df}=1, \mathrm{p}=0.004)$ and August $(G=13.45$, df $=1, p<0.001)$, but not for June $(G=0.48, \mathrm{df}=1, \mathrm{p}=0.488,1-B=0.368)$. Tidal effects did not differ between marsh creeks for any date (June: $G=2.87, \mathrm{df}=1, \mathrm{p}=0.090$, July: $G=0.85, \mathrm{df}=1$, $\mathrm{p}=0.357$, August: $G=1.03, \mathrm{df}=1, \mathrm{p}=0.310$ ).

Soft crab survival in the grassbed (Fig. 4A) did not differ between seagrass sites $(G=2.56, \mathrm{df}=1, \mathrm{p}=$ $0.110,1-B=0.889$ ), but survival did decrease from the beginning to the end of the summer $(G=7.58, \mathrm{df}=2$, $p=0.023)$. This decrease in survival was the same at both sites $(G=0.08, \mathrm{df}=2, \mathrm{p}=0.961)$. In the marsh, soft crab survival did not differ between the small and large creek during June (Fig. $4 \mathrm{~B} ; G=1.82, \mathrm{df}=1, \mathrm{p}=$ $0.177,1-B=0.368$ ) but survival was higher in the small creek during both July $(G=8.12, \mathrm{df}=1, \mathrm{p}<0.001)$ and August $(G=5.34, \mathrm{df}=1, \mathrm{p}=0.021)$. Data from June and July demonstrated that soft crab survival also differed between marsh creeks micro-habitats (Fig. 5). During high tides, survival was greater along creek edges 
A: Seagrass
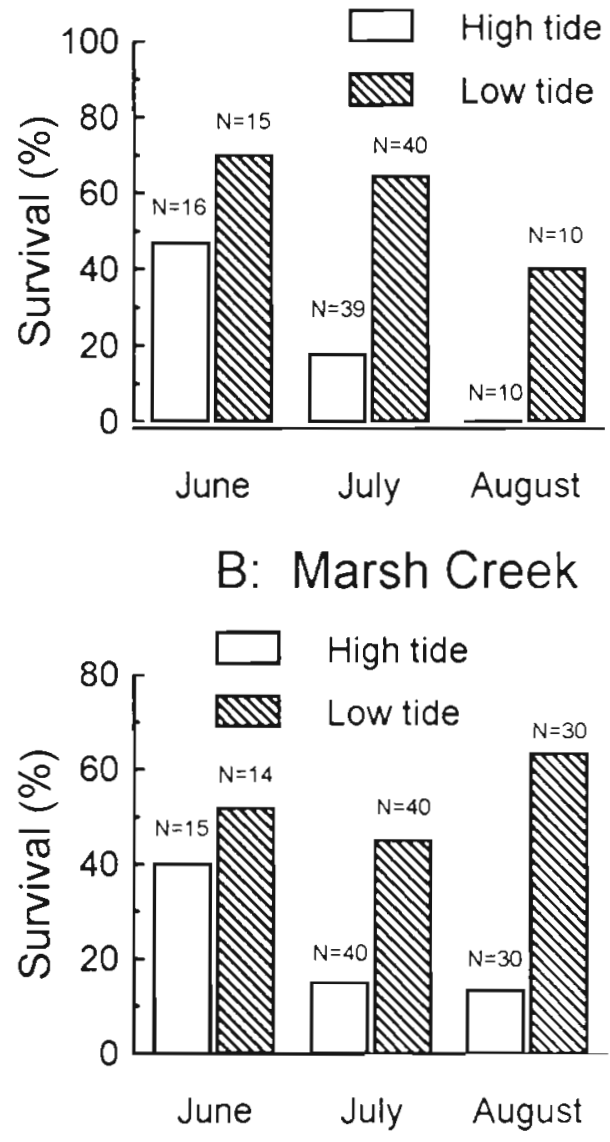

Fig. 3. Callinectes sapidus. Comparison of soft crab survival $(\%)$ between tides in (A) seagrass and (B) marsh creek habitats during June, July and August 1990. Data have been pooled across replicate locations in both seagrass and marsh creek habitats. N: no. of tethered crabs

than in creek centers $(G=3.94, \mathrm{df}=1, \mathrm{p}=0.047)$. This micro-habitat effect was similar in both marsh creeks $(G=1.23, \mathrm{df}=1, \mathrm{p}=0.267)$ and comparable during both June and July $(G=1.80, \mathrm{df}=1, \mathrm{p}=0.180)$

Because survival in the seagrass habitat decreased through the course of the summer, the relationship between relative survival rates in the seagrass and each of the marsh creeks changed as well. Survival of soft crabs tethered in the small marsh creek did not differ from that in the grassbed (both sites combined) during June $(G=0.00$, df $=1, p=1.000,1-B=0.746)$ or July $(G=0.89, \mathrm{df}=1, \mathrm{p}=0.345,1-B=0.898)$, but was greater in the small marsh creek during August $(G=$ $5.17, \mathrm{df}=1, \mathrm{p}=0.023$ ). Large marsh creek survival appeared to be lower than grassbed survival during the months of June and July, but this difference was statistically significant only for July $(G=11.57$, $\mathrm{df}=1, \mathrm{p}<$ 0.001 ). The lack of a significant difference between the

\section{A: Seagrass}

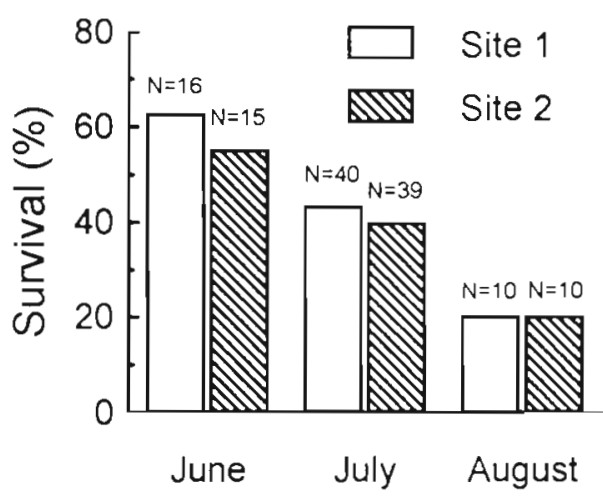

B: Marsh Creek

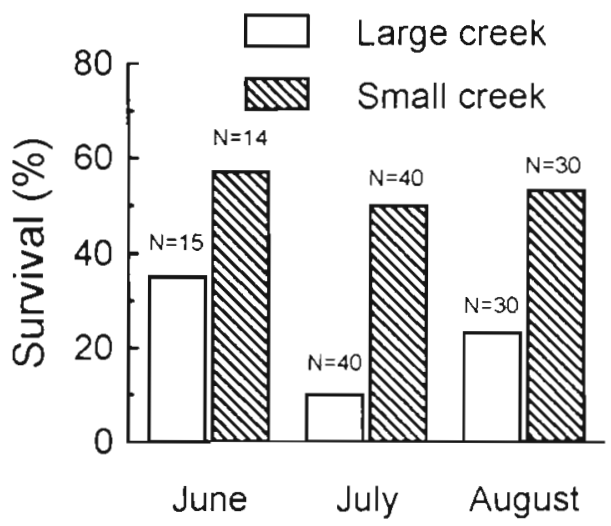

Fig. 4. Callinectes sapidus. Comparison of soft crab survival $(\%)$ between replicate locations in (A) seagrass and (B) marsh creek habitats during June, July and August 1990. Data have been pooled across tides. N: no. of tethered crabs

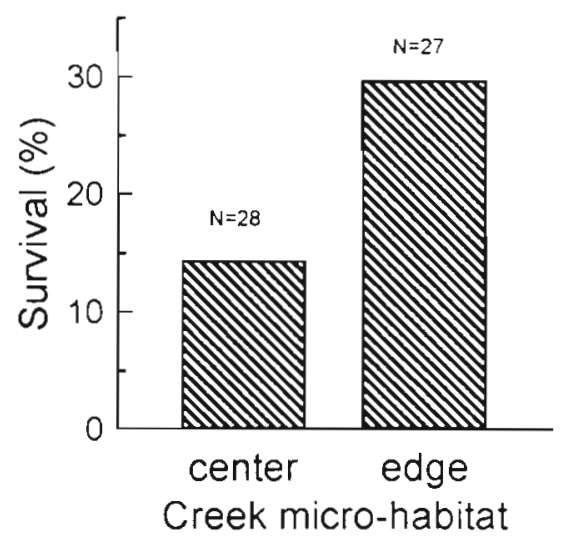

Fig. 5. Callinectes sapidus. Comparison of soft crab survival $(\%)$ in creek centers and along creek edges during high tide. Data have been pooled across months (June and July) and across marsh creeks. N: no. of tethered crabs 
large marsh creek and the grassbed during June $(G=$ 2.53, $\mathrm{df}=1, \mathrm{p}=0.112,1-B=0.630$ ) may have been due to the low replication effort, i.e. the number of crabs tethered, during that month. By August, survival in the large marsh creek was indistinguishable from that in the grassbed $(G=0.11, \mathrm{df}=1, \mathrm{p}=0.740,1-B=0.252)$.

\section{DISCUSSION}

Not surprisingly, our results demonstrate that molting crabs are more susceptible to predation than are hard crabs. While the exoskeleton is being shed, and for a brief time afterward, molting blue crabs are immobile, the chela are useless, and they are unable to flee or defend themselves. Blue crabs were the only predators observed consuming soft crabs and all of the tethering bags recovered without crabs were torn in a manner indicative of blue crab predation. We do not know whether the mesh bag in which crabs were tethered discouraged other potential predators, but recovered soft crabs showed no signs of minor damage, such as might be expected had they been mouthed by fish or had their legs nipped: soft crabs were either intact, torn to pieces, or entirely gone. Similarly, we do not know if our presence frightened away other potential predators, or if other predators may be important during the day, but our data indicate that blue crabs are a major nocturnal predator upon molting blue crabs.

The prevalence of cannibalism may help to explain the temporal periodicity in molting we observed in a previous study (Ryer et al. 1990). In the grassbed and the large marsh creek we studied, blue crabs exhibit a lunar pattern of molting activity characterized by peaks on full moons, lows on new moons, and intermediate molting activity on half moons. We suggested that this might constitute a temporal variant of Hamilton's (1971) 'selfish herd' hypothesis (Reaka 1976), in which temporal aggregation of a vulnerable activity (molting) decreases individual risk of predation through a dilution effect (Bertram 1978). We further argue that temporal aggregation of molting would be most effective in reducing individual risk of mortality when cannibalism is the major threat, i.e. increase in the number of molting individuals decreases the number of potential cannibals (Ryer et al. 1990). Although cannibalism may not be the only source of mortality for molting crabs, our data indicate that it must be considered a potentially important selective pressure having contributed to the evolution of temporal aggregation of molting in blue crabs.

In areas where cannibalism is prevalent, spatial aggregation of molting individuals may also decrease mortality by physically separating molting and nonmolting crabs. Such molt related habitat partitioning has been documented in the Rhode River (Hines et al. 1987). By aggregating, molting crabs may also alleviate risk from other predators through a dilution effect. Further, the physical characteristics of a habitat may provide additional refuge from cannibalism. Blue crabs do not bury into sediment to molt (Ryer \& van Montfrans pers. obs.); hence, above sediment characteristics of the habitat are probably critical in determining refuge value. Prior studies on the refuge value of submerged aquatic vegetation had led us to expect greater survival of tethered soft crabs in seagrass as opposed to marsh creek habitats (Heck \& Thoman 1981, Crowder \& Cooper 1982, Stoner 1982, Orth \& van Montfrans 1987, Wilson et al. 1987, Ryer 1988). We reasoned that the structural complexity of the seagrass environment would make molting crabs less vulnerable than they would be in the marsh creek. This hypothesis also appeared to explain the proportionately greater numbers of premolt, molting, and postmolt blue crabs we had documented in the seagrass bed, as compared to the large marsh creek (Ryer et al. 1990). However, in contrast to these expectations, data from the present study indicate that survival in the grassbed was actually comparable to, or intermediate to that in the 2 marsh creeks. Survival of tethered soft crabs in the grassbed was greater than in the larger marsh creek during July. A similar trend was apparent during June and August, although due to the low power of our statistical tests, we cannot confidently conclude whether or not a differences existed during these 2 months. In relation to the smaller marsh creek, survival of tethered soft crabs in the grassbed was comparable during June and July, but lower during August. These comparisons suggest that the 2 marsh creeks may have had less in common with one another, with respect to their molting refuge value, than each had in common with the grassbed. Comparing the 2 creeks directly, we found higher survival of soft crabs in the larger of the 2 creeks during both July and August. During June, there was a similar trend, but no significant difference, again possibly due to the low number of crabs tethered and resultant low statistical power of our analysis. We suspect that this general difference in survival between the 2 marsh creeks may be attributable to creek morphology. The greater water depth in a large creek may allow increased activity and movement of intermolt crabs, better enabling them to find and cannibalize molting individuals. Alternatively, large creeks may simply have larger blue crab, i.e predator, populations. In any case, these results demonstrate that there may be considerable variability in refuge value between seemingly similar habitats, and suggests that there is no generalized selective advantage associated with molting in seagrass as opposed to marsh creek habitats. 
Within a marsh creek, the micro-habitat in which a crab molts may also influence survival. Cannibalism of tethered soft crabs was lower along the more structurally complex Spartina alterniflora lined creek banks than in the more uniform creek centers. It would appear that $S$. alterniflora stems or cavities along the creek edge provide molting crabs with some degree of protection beyond what is available in the creek center, even though intermolt blue crabs forage extensively along the creek edges and the marsh surface during high tides (Ryer 1987). Wolcott \& Hines (1990) employed ultrasonic telemetry to examine the microhabitats used by premolt male crabs in a tidal marsh creek tributary to the Rhode River, on the central Chesapeake Bay. All 9 of their tagged crabs molted in the shallow waters averaging $28 \mathrm{~cm}$ deep (range 5 to $50 \mathrm{~cm}$ ) at an average distance of $3.5 \mathrm{~m}$ (range 0 to $20 \mathrm{~m}$ ) from vegetated shorelines. Contrary to what would be expected on the basis of our results, these crabs did not molt in emergent vegetation, tree snags or other highly structured habitats, but rather molted in the open Unfortunately, the authors were unable to determine the tidal stage when molting occurred, and it is therefore unclear whether such structured habitats were available when crabs molted.

We expected different effects of tidal stage on soft crab survivorship in seagrass as compared to the marsh creeks. We reasoned that survival in the marsh creeks would be lowest during low tides, when molting refugia along the creek banks were unavailable Mark-recapture data indicated that most intermolt crabs remain in marsh creeks throughout the tidal cycle and are concentrated by receding water at low tide (small marsh creek; van Montfrans et al. 1991) Additionally, blue crab guts are nearly empty at low tide (large marsh creek; Ryer 1987). High densities of hungry crabs would indicate an increased potential for intense aggressive interaction and cannibalism during low tide. However, our results indicate that predation (cannibalism) on soft crabs was actually less during low than during high tides for both July and August. A similar trend was evident during June, but due to the low power of the statistical test employed, we cannot confidently conclude whether or not there was a difference in survival for this month This disparity between our predictions and results may be explained by observations which we did not take into account when formulating our hypotheses. van Montfrans et al. (1991) reported that intermolt blue crabs in marsh creeks burrow into the creek bottom and remain relatively inactive during low tide. Even though crabs were in close proximity to one another, burrowing likely reduced encounter rates between individuals and therefore decreased cannibalism.
As expected, survival of soft crabs in the grassbed was also greater during low tides. We suspect this was caused by differences in encounter rate between predatory crabs and molting individuals at low and high tide. Although blue crabs actively feed throughout the tidal cycle in grassbeds (Ryer 1987), low tide causes grass blades to lie horizontally and form mats that may inhibit the movement of foraging crabs. This matting may further prevent the spread of olfactory cues by inhibiting diffusion and water mixing, thereby making molting crabs more difficult to detect from a distance. Both factors would increase the refuge value of seagrasses during low tide.

It was not our intention to examine seasonal factors as part of this study, but logistics and soft crab availability necessitated spreading our tethering effort over several months. Unfortunately, the number of soft crabs we obtained varied between months, thereby reducing the power of our statistical models to detect seasonal changes in the effects of tide or habitat upon survival. However, one seasonal effect was clear: survival of crabs tethered in the grassbed decreased through the summer. This probably resulted from a combination of 2 factors. First, the density of blue crabs greater than $25 \mathrm{~mm}$, i.e. potential predators, as well as other fish predators increases in Chesapeake Bay grassbeds from June through August (Heck \& Thoman 1984, Orth \& van Montfrans 1987, van Montfrans \& Orth unpubl. data), increasing the potential for cannibalism and predation. Second, the density of Zostera marina decreases over the same period (Orth \& Moore 1986), degrading its refuge value (Stoner 1982, Leber 1985).

At this point it is appropriate to discuss the potential biases associated with utilizing tethering to study soft crab ecology. Peterson \& Black (1994) correctly point out that experimental intervention, such a tethering, can interact with treatments and bias results. For example, in this study we compared the survival of tethered soft crabs with that of tethered hard (intermolt) crabs. Under natural conditions blue crabs are immobile while they struggle free from their old exoskeleton and are unable to flee predators. In contrast, hard crabs are mobile, and because of their considerable armor and chela, are able to aggressively defend themselves. As a result, the tether likely interacted with crab type to exaggerate relative survival estimates for hard crabs, relative to those for soft crabs However, since tethered hard crabs experienced much higher survival than soft crabs, this only strengthens our conclusion that soft crabs are indeed more vulnerable to predation than are hard crabs.

With respect to habitat and tidal effects, we consider it unlikely that tethering interacted with treatments. In another tethering study, involving juvenile intermolt 
blue crabs, no interaction occurred between tethering and habitat (vegetated vs unvegetated substrate) over a range of crab sizes (Pile et al. 1996). Biases in tethering studies should arise when prey have different behavioral mechanisms for avoiding predation in different habitats, or when predators differ between habitats. An example of the former might be an animal that relies upon flight in open habitats, but remains motionless, relying upon cryptic behavior in vegetated habitats. Presumably, a tether would decrease the effectiveness of flight (Zimmer-Faust et al. 1994), but would have little influence upon the effectiveness of cryptic behavior. Molting crabs are incapable of flight or defense. What little protection they have is associated with where and when they molt, and this was controlled in our experimental design. As a result, predation upon soft crabs was determined by encounter rates with predators, and as such, was not likely to be influenced by our tethering technique, regardless of treatment (Barbeau \& Scheibling 1994). With respect to predators themselves, it has been argued that tethering may render prey vulnerable to predators that are not normally a threat. Comparisons between habitats, for instance, will be biased if a normally benign predator is particularly abundant in one habitat. Although we can not rule out predation from other sources, all of our observations and physical evidence indicate intermolt blue crabs were the major predators upon soft crabs, regardless of habitat or tide. Since there is no reason to suspect that tethering interacted with treatments or substantially altered vulnerability to predator, other than with respect to the duration of vulnerability, we conclude that tethering soft crabs is an appropriate methodology for examining relative cannibalism rates upon molting crabs under a variety of different environmental conditions. The efficacy of tethering with respect to other predators might be further evaluated by examining the interactions between soft crabs and potential predators in the laboratory (Pile et al. 1996), or by utilizing remote monitoring systems in the field.

In conclusion, molting crabs are more vulnerable to cannibalism than are hard crabs, and although our tethering methodology may have underestimated predation by other species, cannibalism may be an important source of mortality during ecdysis. Our data suggest that where a crab molts, tidal stage and whether other crabs are also molting may affect survival. Collectively, these factors could reasonably be expected to have influenced the evolution of crab behavior which determines where and when blue crabs choose to molt. Determining whether blue crabs do in fact actively seek out particular habitats or locations for use as molting refugia, or whether passive mechanisms are involved, awaits further investigation. Lastly, in our discussion we have concentrated upon the significant effects reported, but have also indicated areas where our results are inconclusive due to the low statistical power of particular tests. Future research in this area would benefit from greater replication, i.e. number of crabs tethered, thereby increasing the statistical power of analyses.

Acknowledgements. We thank April Evans and Michael Burger for their assistance in the field. This work was supported in part by the National Sea Grant College Program of the National Oceanographic and Atmospheric Administration, U. S. Department of Commerce, under Grant NA90-AAD-SG045 to J.v.M. and a grant from the Lerner-Gray Fund for Marine Research, of the American Museum of Natural History, to C.R. This is contribution no. 2048 from the Virginia Institute of Marine Science, College of William \& Mary. Gloucester Point, VA 23062

\section{LITERATURE CITED}

Barbeau MA, Scheibling RE (1994) Procedural effects of prey tethering experiments: predation of juvenile scallops by crabs and sea stars. Mar Ecol Prog Ser 111:305-310

Bertram BCR (1978) Living in groups: predators and prey. In: Krebs JR, Davies NB (eds) Behavioural ecology. Blackwell Scientific Publications, Oxford, p. 64-96

Cohen J (1977) Statistical power analysis for the behavioral sciences. Academic Press, Orlando, FI

Crowder LB, Cooper WE (1982) Habitat structural complexity and the interaction between bluegills and their prey. Ecology 63:1802-1813

Fienberg SE (1980) The analysis of cross classified categorical data. MIT Press, Cambridge, MA

Hamilton WD (1971) Geometry of the selfish herd. J Theor Biol 31:295-311

Heck KL Jr, Thoman TA (1981) Experiments on predator-prey interactions in vegetated aquatic habitats. J Exp Mar Biol Ecol 53:125-134

Hines AH, Lipcius RN, Haddon AM (1987) Population dynamics and habitat partitioning by size, sex and molt stage of blue crabs Callinectes sapidus in a subestuary of the central Chesapeake Bay. Mar Ecol Prog Ser 36: $55-64$

Leber KM (1985) The influence of predatory decapods, refuge and microhabitat selection on seagrass communities. Ecology 66:1951-1964

Lipcius RN, Hernkind WF (1982) Molt cycle alterations in behavior, feeding and diel rhythms of a decapod crustacean, the spiny lobster Panulirus argus. Mar Biol 68: $241-252$

Oesterling MJ (1984) Manual for handling and shedding blue crabs (Callinectes sapidus). SRAMSOE No. 271, Virginia Institute of Marine Science, College of William \& Mary, Gloucester Point, VA

Orth RJ, Moore KA (1986) Seasonal and year-to-year variations in the growth of Zostera Marina L. (eelgrass) in the lower Chesapeake Bay. Aquat Bot 24:335-341

Orth RJ, van Montfrans J (1987) Utilization of a seagrass meadow and tidal marsh creek by blue crabs Callinectes sapidus. I. Seasonal and annual variations in abundance with emphasis on post-settlement juveniles. Mar Ecol Prog Ser 41:283-294

Peterson CH, Black R (1994) An experimentalist's challenge when artifacts of intervention interact with treatments. Mar Ecol Prog Ser 111:289-297 
Pile AJ, Lipcius RN, van Montfrans J, Orth RJ (1996) Densitydependent settler-recruit-juvenile relationships in blue crabs. Ecol Monogr 66:277-300

Reaka ML (1976) Lunar and tidal periodicity of molting and reproduction in stomatopod Crustacea: a selfish herd hypothesis. Biol Bull 150:468-490

Ryer CH (1987) Temporal patterns of feeding by blue crab (Callinectes sapidus) in a tidal marsh creek and adjacent seagrass meadow in the lower Chesapeake Bay. Estuaries $10: 136-140$

Ryer CH (1988) Pipefish foraging: effects of fish size, prey size and altered habitat complexity. Mar Ecol Prog Ser 48:37-45

Ryer CH, van Montfrans J, Orth RJ (1990) Utilization of a seagrass meadow and tidal marsh creek by blue crabs Callinectes sapidus II. Spatial and temporal patterns of molting. Bull Mar Sci 46:95-104

Shirley MA, Hines AH, Wolcott TG (1990) Adaptive significance of habitat selection by molting adult blue crabs Callinectes sapidus (Rathbun) within a subestuary of central Chesapeake Bay. J Exp Mar Biol Ecol 140:107-119

This article was presented by K. L. Heck $J r$, Dauphin Island, Alabama, USA
Stoner AW (1982) The influence of benthic macrophytes on the foraging behavior of pinfish, Lagodon rhomboides (Linnaeus). J Exp Mar Biol Ecol 58:271-284

Tamm GR, Cobb JS (1978) Behavior and the crustacean molt cycle: changes in aggression of Homarus americanus. Science 200:79-81

van Montfrans J, Ryer C. Orth R (1991) Population dynamics of blue crabs Callinectes sapidus Rathbun in a lower Chesapeake Bay tidal marsh creek. J Exp Mar Biol Ecol 153:1-14

Wilson KA, Heck KL Jr, Able KW (1987) Juvenile blue crab, Callinectes sapidus, survival: and evaluation of eelgrass, Zostera marina, as refuge. Fish Bull US 85:53-58

Wolcott TG, Hines AH (1990) Ultrasonic telemetry of small-scale movements and microhabitat selection by molting blue crabs (Callinectes sapidus). Bull Mar Sci 46:83-94

Zimmer-Faust RK, Fielder DR, Heck KL Jr, Coen LD, Morgan SG (1994) Effects of tethering on predatory escape by juvenile blue crabs. Mar Ecol Prog Ser 111:299-303

Manuscript first received: January 29, 1996

Revised version accepted: January 7, 1997 